\title{
Pancrelipase treatment in a patient with the history of Roux-en-Y gastric bypass operation that developed resistant hypocalcemia secondary to total thyroidectomy
}

\author{
Baldane S, Ipekci SH, Kebapcilar L \\ Department of Internal Medicine, Division of Endocrinology and Metabolism, \\ Faculty of Medicine, Selcuk University, Konya, Turkey \\ E-mail: baldane42@hotmail.com
}

\begin{abstract}
Objective. Roux-en-Y gastric bypass (RYGB) is an independent risk factor for moderate hypocalcaemia and may lead to the development of resistant hypocalcaemia following thyroid surgery.

Subject and Results. A 35-year old female patient was referred to our hospital by her family physician for treatment of resistant hypocalcaemia. The patient underwent RYGB three years ago and a total thyroidectomy for a benign thyroid nodule one year ago. Calcitriol, calcium carbonate, magnesium oxide, and ergocalciferol therapeutic dosages were incremented. Despite dosage increments, the desired calcium levels were not achieved. In the sixth month after admission to our hospital, pancrelipase was added to patient's treatment scheme. On the following visit, a good calcium increase had been achieved.

Conclusion. This report presents a case history of RYGB and resistant hypocalcaemia, which developed after thyroid surgery and positively responded to pancrelipase treatment.
\end{abstract}

Key words: bariatric surgery, hypocalcaemia, hypoparathyroidism, thyroidectomy

Hypocalcaemia is a well-defined complication of thyroid surgery, which develops as a result of temporary or permanent injury of the parathyroid glands (Delbridge et al. 1999). Roux-en-Y gastric bypass (RYGB) is an independent risk factor for moderate hypocalcaemia related to the decreased production of gastric acid and the absorption of calcium and vitamin D by the intestinal surface (Slater et al. 2004). This condition may lead to the development of resistant hypocalcaemia following thyroid surgery in patients with a history of RYGB. This report presents a case history of RYGB and resistant hypocalcaemia, which developed after thyroid surgery but responded well to pancrelipase treatment.

\section{Subject and Results}

A 35-year old female patient was referred to our hospital by her family physician for treatment of resistant hypocalcaemia. The patient underwent RYGB three years ago and a total thyroidectomy for a benign thyroid nodule one year ago.

At the time of her admission, the laboratory parameters were as follows: calcium (Ca): $7.1 \mathrm{mg} / \mathrm{dl}$; phosphorus (P): $4.4 \mathrm{mg} / \mathrm{dl}$; magnesium $(\mathrm{Mg}): 1.70 \mathrm{mg} / \mathrm{dl}$; 25-hydroxyvitamin D [25(OH)D]: $18 \mathrm{ng} / \mathrm{ml}$; parathormone (PTH): $9 \mathrm{pg} / \mathrm{ml}$; thyroid stimulating hormone (TSH): $3.2 \mu \mathrm{IU} / \mathrm{ml}$; albumin: $4.2 \mathrm{~g} / \mathrm{dl}$. To the patient levothyroxine $100 \mu \mathrm{g} / \mathrm{day}$, calcitriol $1 \mu \mathrm{g} / \mathrm{day}$,

Corresponding author: Suleyman Baldane, M.D., Department of Internal Medicine, Division of Endocrinology and Metabolism, Faculty of Medicine, Selcuk University, 42075 Konya, Turkey; phone: +903322244685; fax: +903322412184; 
and calcium carbonate $4 \mathrm{~g} /$ day was prescribed. The treatment scheme of the patient was as follows: calcitriol $2 \mu \mathrm{g} / \mathrm{day}$, calcium carbonate $6 \mathrm{~g} / \mathrm{day}$, magnesium oxide $400 \mathrm{mg} 1 \times 1$, ergocalciferol $50000 \mathrm{IU} /$ day for one week followed by 50000 IU/14 days, sunlight exposure (20 min per day), and a recommended diet.

The control biochemical values obtained after one month of treatment were as follows: Ca: $7.2 \mathrm{mg} / \mathrm{dl}$, P: $4.2 \mathrm{mg} / \mathrm{dl} ; \mathrm{Mg}: 1.98 \mathrm{mg} / \mathrm{dl} ; 25(\mathrm{OH}) \mathrm{D}: 27 \mathrm{ng} / \mathrm{ml}$. The treatment scheme was: calcitriol $3 \mu \mathrm{g} /$ day and calcium carbonate $8 \mathrm{~g} /$ day. The control biochemical parameters obtained after two months of treatment were as follows: Ca: $7.4 \mathrm{mg} / \mathrm{dl} ; \mathrm{P}: 4.0 \mathrm{mg} / \mathrm{dl} ; \mathrm{Mg}$ :
$1.96 \mathrm{mg} / \mathrm{dl} ; 25(\mathrm{OH}) \mathrm{D}: 38 \mathrm{ng} / \mathrm{ml}$. Despite dosage increments in two subsequent visits, the expected results of the treatment were not achieved.

In the sixth month after admission to our hospital, the patient's treatment scheme was as follows: calcitriol $6 \mu \mathrm{g} /$ day, calcium carbonate $12 \mathrm{~g} / \mathrm{day}$, and ergocalciferol 50,000 IU/30 days. Pancrelipase (8000 USP units of amylase, 10000 USP units of lipase, and 600 USP units protease) (three times a day with meals) was added to the treatment regimen. On the following visit, a good calcium increase had been achieved (Ca: $9.0 \mathrm{mg} / \mathrm{dl}, \mathrm{P}: 3.9 \mathrm{mg} / \mathrm{dl}$ ). Decrements in calcitriol, calcium carbonate, and ergocalciferol dosages were

Table 1

Laboratory variables and treatment modifications during follow-up

\begin{tabular}{|c|c|c|c|c|c|c|c|}
\hline & $\begin{array}{c}\mathrm{Ca} \\
(\mathrm{mg} / \mathrm{dl})^{\mathrm{a}}\end{array}$ & $\begin{array}{c}\mathbf{P} \\
(\mathrm{mg} / \mathrm{dl})\end{array}$ & $\underset{(\mathrm{mg} / \mathrm{dl})}{\mathrm{Mg}}$ & $\begin{array}{c}\text { PTH } \\
(\mathrm{pg} / \mathrm{ml})\end{array}$ & $\begin{array}{l}25(\mathrm{OH}) \mathrm{D} \\
(\mathrm{ng} / \mathrm{ml})\end{array}$ & $\begin{array}{l}\text { Urine calcium } \\
(\mathrm{mg} / \text { day })\end{array}$ & Treatment \\
\hline Normal range & $8.5-10.2$ & $2.3-4.7$ & $1.9-2.7$ & $10-65$ & $30-80$ & $100-300$ & \\
\hline $\begin{array}{l}\text { At the time } \\
\text { of admission }\end{array}$ & 7.1 & 4.4 & 1.70 & 9 & 18 & 32 & $\begin{array}{l}\text { calcitriol } 1 \mu \mathrm{g} / \text { day } \\
\text { calcium carbonate } 4 \mathrm{~g} / \text { day }\end{array}$ \\
\hline $\begin{array}{l}1^{\text {st }} \text { month } \\
\text { of admission }\end{array}$ & 7.2 & 4.2 & 1.98 & -- & 27 & -- & $\begin{array}{l}\text { calcitriol } 2 \mu \mathrm{g} / \mathrm{g} \\
\text { calcium carbonate } 6 \mathrm{~g} / \text { day } \\
\text { magnesium oxide } 400 \mathrm{mg} / \text { day } \\
\text { ergocalciferol } 50000 \mathrm{IU} / 14 \text { days }\end{array}$ \\
\hline $\begin{array}{l}3^{\text {rd }} \text { months } \\
\text { of admission }\end{array}$ & 7.4 & 4.0 & 1.96 & -- & 38 & -- & $\begin{array}{l}\text { calcitriol } 3 \mu \mathrm{g} / \text { day } \\
\text { calcium carbonate } 8 \mathrm{~g} / \text { day } \\
\text { magnesium oxide } 400 \mathrm{mg} / \text { day } \\
\text { ergocalciferol } 50000 \mathrm{IU} / 14 \text { days }\end{array}$ \\
\hline $\begin{array}{l}4^{\text {th }} \text { months } \\
\text { of admission }\end{array}$ & 7.2 & 4.2 & 2.0 & -- & -- & 41 & $\begin{array}{l}\text { calcitriol } 4 \mu \mathrm{g} / \text { day } \\
\text { calcium carbonate } 9 \mathrm{~g} / \text { day } \\
\text { magnesium oxide } 400 \mathrm{mg} / \text { day } \\
\text { ergocalciferol } 50000 \mathrm{IU} / 14 \text { days }\end{array}$ \\
\hline $\begin{array}{l}6^{\text {th }} \text { months } \\
\text { of admission }\end{array}$ & 7.3 & 4.1 & -- & 8 & 48 & -- & $\begin{array}{l}\text { calcitriol } 5 \mu \mathrm{g} / \text { day } \\
\text { calcium carbonate } 10 \mathrm{~g} / \text { day } \\
\text { magnesium oxide } 400 \mathrm{mg} / \text { day } \\
\text { ergocalciferol } 50000 \mathrm{IU} / 14 \text { days }\end{array}$ \\
\hline $\begin{array}{l}7^{\text {th }} \text { months } \\
\text { of admission }\end{array}$ & 9.0 & 3.9 & -- & -- & -- & -- & $\begin{array}{l}\text { calcitriol } 6 \mu \mathrm{g} / \text { day } \\
\text { calcium carbonate } 12 \mathrm{~g} / \text { day } \\
\text { magnesium oxide } 400 \mathrm{mg} / \text { day } \\
\text { ergocalciferol } 50000 \mathrm{IU} / 30 \text { days } \\
\text { pancrelipase } 3 \times 1\end{array}$ \\
\hline $\begin{array}{l}8^{\text {th }} \text { months } \\
\text { of admission }\end{array}$ & 8.8 & 4.0 & 1.95 & -- & -- & 43 & $\begin{array}{l}\text { calcitriol } 4 \mu \mathrm{g} / \text { day } \\
\text { calcium carbonate } 10 \mathrm{~g} / \text { day } \\
\text { magnesium oxide } 400 \mathrm{mg} / \text { day } \\
\text { ergocalciferol } 50000 \mathrm{IU} / 30 \text { days } \\
\text { pancrelipase } 3 \times 1\end{array}$ \\
\hline $\begin{array}{l}9^{\text {th }} \text { months } \\
\text { of admission }\end{array}$ & 8.7 & 4.1 & -- & -- & 44 & -- & $\begin{array}{l}\text { calcitriol } 4 \mu \mathrm{g} / \text { day } \\
\text { calcium carbonate } 8 \mathrm{~g} / \text { day } \\
\text { magnesium oxide } 400 \mathrm{mg} / \text { day } \\
\text { ergocalciferol } 50000 \mathrm{IU} / 30 \text { days } \\
\text { pancrelipase } 3 \times 1\end{array}$ \\
\hline
\end{tabular}

a All calcium levels were corrected by albumin levels. Abbreviations: $\mathrm{Ca}$ - calcium; P - phosphorus; Mg - magnesium; PTH - parathormone, 25(OH)D - 25-hydroxyvitamin D 
made in the subsequent visits. In the patient's last visit, the following treatment was prescribed: calcium and phosphorus were measured at $8.7 \mathrm{mg} / \mathrm{dl}$ and $4.1 \mathrm{mg} / \mathrm{dl}$, respectively, with pancrelipase $3 \times 1$, calcitriol $4 \mu \mathrm{g} / \mathrm{day}$, calcium carbonate $8 \mathrm{~g} / \mathrm{day}$, ergocalciferol 50000 IU/30 days and magnesium oxide $400 \mathrm{mg} /$ day. Table 1 shows the laboratory findings and treatment alterations for the patient.

\section{Discussion}

Bariatric surgery procedures have been increasingly performed worldwide during the last ten years. About 200000 bariatric surgery operations are performed in United States annually (Kohn et al. 2009; Lo Menzo et al. 2015). The most common procedure is RYGB, which comprises about $80 \%$ of all bariatric surgery cases (Kohn et al. 2009; Lo Menzo et al. 2015).

RYGB is a malabsorptive bariatric surgical method in which the duodenum and jejunum are bypassed. Most parts of the stomach and ileum are bypassed by anastomosing the distal ileum to a small gastric pouch. It is known that malabsorptive procedures such as RYGB may cause a wide range of nutritional deficiencies, including protein, iron, vitamin $B_{12}$, folic acid, calcium, magnesium, vitamin $\mathrm{D}$, and other fat soluble vitamins (Toh et al. 2009).

Dietary calcium is mainly absorbed by the duodenum and proximal jejunum (Slater et al. 2004). In the case of low dietary calcium intake in a healthy adult, $80-100 \%$ of calcium may be absorbed by the duodenum via a vitamin-D dependent transcellular active transport mechanism (Johnson et al. 2006). However, if the duodenum is by-passed, calcium is absorbed by a less effective paracellular transport mechanism, which is located in the ileum. It normally contributes from $0-20 \%$ to calcium absorption (Johnson et al. 2006). Another mechanism by which RYGB disturbs calcium absorption is low acidity in the formed gastric pouch compared to normal gastric content (Miller and Smith 2006). In addition, patients who undergo bariatric surgery have fat malabsorption due to the insufficient mixture of biliary salts and dietary fat, which causes deficiencies in mainly vitamin D and other fat-soluble vitamins (Johnson et al. 2006).

Vitamin D deficiency and insufficiency are very common in obese individuals, independent of bariatric surgery (Bischof et al. 2006; Carlin et al. 2006). In obese people, both cutaneous vitamin D synthesis and the intestinal absorption of dietary vitamin $\mathrm{D}$ intake are decreased (Wortsman et al. 2000). Dietary vitamin $\mathrm{D}$ is mainly absorbed by the jejunum and ileum (Bloomberg et al. 2005), and in obese individu- als, the intestinal absorption of vitamin $\mathrm{D}$ further decreases after RYGB.

In addition to these causes, it is known that following bariatric surgery patients take only half of the amount of daily-recommended vitamin $\mathrm{D}$ and in many patients intolerance to calcium-rich foods after surgery develops (Salinger and Moore 2010; Nguyen et al. 2011). Consequently, these patients become prone to vitamin $\mathrm{D}$ deficiency and calcium metabolism disorder. In the first four years following bariatric surgery, the incidences of hypocalcaemia and vitamin D deficiency are $15-48 \%$ and $50-63 \%$, respectively, independent of multi-vitamin support (Hundahl et al. 2000; Tondapu et al. 2009). For this reason, current guidelines have recommend calcium (1200 mg/day) and 25(OH)D (800 IU/day) for patients after bariatric surgery (Mechanick et al. 2008).

Thyroidectomy is a commonly performed surgical procedure with a low complication rate. Hypocalcaemia is a well-defined complication of thyroid surgery. Although a wide range of statistical values has been reported in the literature, hypocalcaemia develops in about $10 \%$ of patients and permanent hypoparathyroidism requiring long-term calcium supplementation occurs in about $1 \%$ of patients (Delbridge et al. 1999; Hundahl et al. 2000). In the case of RYGB-related hypocalcaemia, normocalcaemia may be achieved by secondary hyperparathyroidism. However, this compensation mechanism does not work in the case of iatrogenic hypoparathyroidism. Therefore, total thyroidectomy is a risk factor for the development of resistant hypocalcaemia in patients with a history of RYGB surgery.

Case histories of patients who developed resistant hypocalcaemia secondary to total thyroidectomy after RYGB surgery have been reported in the literature (Durr et al. 2009; Pietras and Holick 2009; Salinger and Moore 2010; Gross et al. 2014; Panazzolo et al. 2014; Alfonso et al. 2015). Unlike other cases, Panazzolo et al. (2014) have used pancrelipase in the treatment, speculating that it might enhance the absorption of fat and fat soluble vitamins (especially vitamin $\mathrm{D}$ ), and they obtained a successful result. The only relevant original research found in the literature is a retrospective study conducted by McKenzie et al. (2013). In this study, data of 19 patients who underwent thyroidectomy after RYGB were compared with the data of a control group. The incidences of symptomatic hypocalcaemia, postoperative intravenous calcium requirement, and duration of hospitalization, were found to be significantly higher in the patients underwent to thyroidectomy (McKenzie et al. 2013). 
It has been shown that calcium citrate was better absorbed than calcium carbonate after gastric bypass because of low acid secretion (Johnson et al. 2006). Because calcium citrate is not available in our country, we used calcium carbonate in oral calcium treatment in our case. Thiazid diuretics decreased the excretion of urinary calcium by increasing calcium absorption by the distal tubule. Testa et al. (2006) have suggested that calcitriol and a low dosage of thiazid diuretic treatment were protective against hypocalcaemia after thyroid surgery. Because the urinary calcium levels in our patient were low and thiazid treatment was not tested on this patient group, we did not apply thiazid diuretic treatment in this case. Although high dosages of oral calcium and vitamin D (calcitriol and cholecalciferol) treatment were given and magnesium was added to the treatment, a sufficient treatment response was not achieved. For this reason, we applied the pancrelipase treatment, which has previously been reported by Panazzolo et al. (2014). A quite good treatment response was obtained with pancrelipase, the desired calcium levels were achieved and the dosages of other drugs were partially decreased.

The treatment of iatrogenic hypoparathyroidism in patients with RYGB history may create difficulties for physicians. In addition to standard calcium and vitamin $\mathrm{D}$ replacement treatment, pancrelipase may be utilized in resistant cases. Pancrelipase may have a positive effect on calcium absorption by increasing the absorption of vitamin D. Further controlled trials are required to determine the importance and appropriateness of pancrelipase treatment in this patient group.

\section{References}

Alfonso B, Jacobson AS, Alon EE, Via MA. Previous gastric bypass surgery complicating total thyroidectomy. Ear Nose Throat J 94, 12-16, 2015.

Bischof MG, Heinze G, Vierhapper H. Vitamin D status and its relation to age and body mass index. Horm Res 66, 211-215, 2006.

Bloomberg RD, Fleishman A, Nalle JE, Herron DM, Kini S. Nutritional deficiencies following bariatric surgery: What have we learned? Obes Surg 15, 145-154, 2005.

Carlin AM, Rao DS, Meslemani AM, Genaw JA, Parikh NJ, Levy S, Bhan A, Talpos GB. Prevalence of vitamin D depletion among morbidly obese patients seeking gastric bypass surgery. Surg Obes Relat Dis 2, 98-103, 2006.

Delbridge L, Guinea AI, Reeve TS. Total thyroidectomy for bilateral benign multinodular goiter: effect of changing practice. Arch Surg 134, 1389-1393, 1999.

Durr ML, Saunders JR, Califano JA, Tufano RP, Koch WM, Ha PK. Severe hypocalcemia complicating thyroid surgery after Roux-en-Y gastric bypass procedure. Arch Otolaryngol Head Neck Surg 135, 507-510, 2009.

Gross JA, Olsen SM, Koch CA, Moore EJ. Severe symptomatic hypocalcemia following total thyroidectomy in a patient with a history of Roux-en-Y gastric bypass surgery. Ear Nose Throat J 93, 6-11, 2014.

Hundahl S, Cady B, Cunningham M, Mazzaferri E, McKee RF, Rosai J, Shah JP, Fremgen AM, Stewart AK, Holzer S. Initial results from a prospective cohort study of 5583 cases of thyroid carcinoma treated in the United States during 1996. Cancer 89, 202-217, 2000.

Johnson JM, Maher JW, DeMaria EJ, Downs RW, Wolfe LG, Kellum JM. The long-term effects of gastric bypass on vitamin D metabolism. Ann Surg 243, 701-704, 2006.

Kohn GP, Galanko JA, Overby DW, Farrell TM. Recent trends in bariatric surgery case volume in the United States. Surgery 146, 375-380, 2009.

Lo Menzo E, Szomstein S, Rosenthal RJ. Changing trends in bariatric surgery. Scand J Surg 104, 18-23, 2015.

McKenzie TJ, Chen Y, Hodin RA, Shikora SA, Hutter MM, Gaz RD, Moore FD Jr, Lubitz CC. Recalcitrant hypocalcemia after thyroidectomy in patients with previous Roux-en-Y gastric bypass. Surgery 154, 1300-1306, 2013.

Mechanick JI, Kushner RF, Sugerman HJ, Gonzalez-Campoy JM, Collazo-Clavell ML, Guven S, Spitz AF, Apovian CM, Livingston EH, Brolin R, Sarwer DB, Anderson WA, Dixon J. American Association of Clinical Endocrinologists, The Obesity Society, and American Society for Metabolic \& Bariatric Surgery Medical Guidelines for Clinical Practice for the perioperative nutritional, metabolic, and nonsurgical support of the bariatric surgery patient. Surg Obes Relat Dis 4, S109-S184, 2008.

Miller AD, Smith KM. Medication and nutrient administration considerations after bariatric surgery. Am J Health Syst Pharm 63, 1852-1857, 2006.

Nguyen NT, Masoomi H, Magno CP, Nguyen XT, Laugenour K, Lane J. Trends in use of bariatric surgery 2003-2008. J Am Coll Surg 213, 261-216, 2011. 
Panazzolo DG, Braga TG, Bergamim A, Pires B, Almeida H, Kraemer-Aguiar LG. Hypoparathyroidism after Rouxen-Y gastric bypass--a challenge for clinical management: a case report. J Med Case Rep 8, 357, 2014.

Pietras SM, Holick MF. Refractory hypocalcemia following near-total thyroidectomy in a patient with a prior Rouxen-Y gastric bypass. Obes Surg 19, 524-526, 2009.

Salinger EM, Moore JT. Profound hypocalcemia after neartotal thyroidectomy in a roux-en-Y gastric bypass patient. Am Surg 76, 7-8, 2010.

Slater GH, Ren CJ, Siegel N, Williams T, Barr D, Wolfe B, Dolan K, Fielding GA. Serum fat-soluble vitamin deficiency and abnormal calcium metabolism after malabsorptive bariatric surgery. J Gastrointest Surg 8, 48-55, 2004.

Testa A, Fant V, De Rosa A, Fiore GF, Grieco V, Castaldi P, Persiani R, Rausei S, D’ugo D, De Rosa G. Calcitriol plus hydrochlorothiazide prevents transient post-thyroidectomy hypocalcemia. Horm Metab Res 38, 821-826, 2006.

Toh SY, Zarshenas N, Jorgensen J. Prevalence of nutrient deficiencies in bariatric patients. Nutrition 25, 1150-1156, 2009.

Tondapu P, Provost D, Adams-Huet B, Sims T, Chang C, Sakhaee K. Comparison of the Absorption of calcium carbonate and calcium citrate after roux-en-Y gastric bypass. Obes Surg 19, 1256-1261, 2009.

Wortsman J, Matsuoka LY, Chen TC, Lu Z, Holick MF. Decreased bioavailability of vitamin D in obesity. Am J Clin Nutr 72, 690-693, 2000. 